\title{
Bioavailability of transglutaminase cross-linked sodium casein hydrolysates
}

\author{
M. Cermeño ${ }^{1,2}$, Y. O’Callaghan ${ }^{1}$, N. O’Brien ${ }^{1}$ and R.J. FitzGerald ${ }^{2}$ \\ ${ }^{1}$ School of Food and Nutritional Sciences, University College Cork, Cork, Republic of Ireland and ${ }^{2}$ Department of Life \\ Sciences, University of Limerick, Limerick, Republic of Ireland
}

Enzymatic hydrolysis of casein leads to the generation of peptides with bioactive properties ${ }^{(1)}$. We have previously reported that the addition of transglutaminase (TGase) prior to hydrolysis with Prolyve yielded cross-linked sodium caseinate (NaCN) hydrolysates that demonstrated anti-inflammatory properties in Jurkat $\mathrm{T}$ cells ${ }^{(2)}$. However, hydrolysates may need to be absorbed by the intestinal epithelial cells to be functional. The aim of the present study was to assess the bioavailability of these TGase cross-linked $\mathrm{NaCN}$ hydrolysates using a Caco-2 cell model.

Caco-2 cells were allowed to differentiate for 21 days in Transwell ${ }^{\circledR}$ plates. Hydrolysate samples $(2 \%(\mathrm{v} / \mathrm{v}))$ were diluted in $1.5 \mathrm{ml}$ Hank's Balanced Solution (HBBS) and added to the apical side of the monolayers, while $1.5 \mathrm{ml}$ HBBS without samples was added in the basolateral chamber. Chambers were then incubated at $37^{\circ} \mathrm{C}$ for $120 \mathrm{~min}$ and the apical and basolateral samples were taken and stored at $-18{ }^{\circ} \mathrm{C}$ until further analysis. Peptide transport was analysed by quantifying the amino nitrogen transported from the apical to the basolateral chamber using the TNBS method ${ }^{(3)}$.

(a)

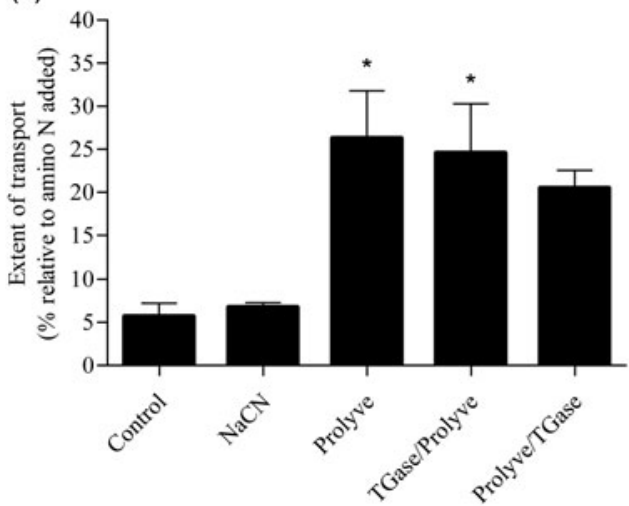

(b)

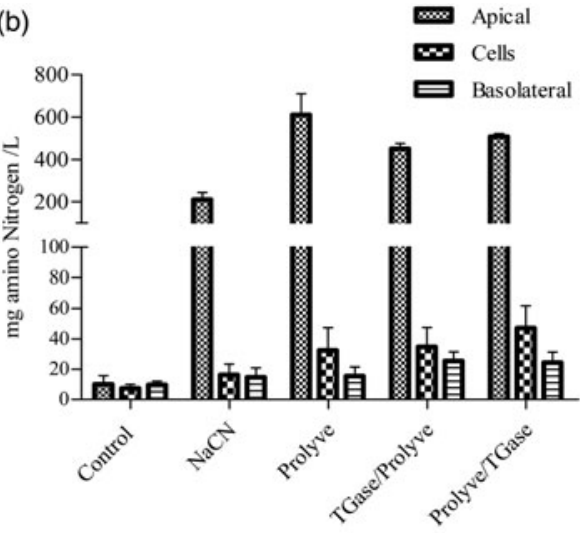

Fig. 1. Extent of transport of the hydrolysates (a) and concentration of amino nitrogen after 120 min (b). Mean for three independent experiments * Denotes significance $(\mathrm{p}<0.05)$ compared to $\mathrm{NaCN}$.

The non-cross linked hydrolysate (Prolyve) and cross-linking pre-hydrolysis (TGase/Prolyve) samples had the highest extent of transport (Fig. 1a). Transport was significantly higher compared with NaCN $(\mathrm{p}<0.05)$. Although cross-linked post hydrolysis (Prolyve/TGase) showed a high extent of transport, it was not significantly different $(p>0.05)$ from NaCN. Fig. 1b indicates that part of the hydrolysate amino Nitrogen was retained by the cells. The results overall confirm that hydrolysate peptides are able to pass through the epithelial intestinal barrier, however, more studies are necessary to demonstrate that the hydrolysates remain bioactive after transport.

Funding for this research was provided under the National Development Plan, through the Food Institutional Research Measure, administered by the Department of Agriculture, Food and the Marine, Ireland.

1. Phelan M, Aherne A, FitzGerald RJ, et al. (2009) Int Dairy J 19, 643-654.

2. O'Sullivan D, Lahart N, O'Callaghan et al. (2013) Int Dairy J 33, 49-54.

3. Spellman D, McEvoy E, O’Cuinn G, et al. (2003) Int Dairy J 13, 447-453. 